\title{
MOLECULAR IDENTIFICATION OF TWO GOBI FISHES OF BANGLADESH USING CYTOCHROME OXIDASE SUBUNIT I (COI) GENE SEQUENCES
}

\author{
Mehnus Tabassum*, Hawa Jahan and Gulshan Ara Latifa \\ Department of Zoology, University of Dhaka, Dhaka-1000, Bangladesh
}

\begin{abstract}
DNA barcoding has been proposed as a means of quick species identification using a short standardized segment of DNA. Two species (Eleotris fusca and Glossogobius giuris) from the family Gobiidae and Eleotridae were selected for DNA barcoding using samples collected from different regions of Bangladesh. Cytochrome Oxidase Subunit I (COI) gene was sequenced from two different gobi fishes and compared with two previously published similar sequences from the genera Eleotris and Glossogobius. Multiple sequence alignment and the molecular systematic study were performed. The DNA barcode technique identified the two species. The study provides a good example of how DNA barcoding can build upon its primary mission of species identification and use available data to integrate genetic variation investigated at the local scale into a global framework.
\end{abstract}

Key words: DNA barcoding, COI gene, gobi fish

\section{INTRODUCTION}

Bangladesh is blessed with various inland water bodies, which are very rich in fish species diversity and bears a huge potential for fisheries sector (Rahman et al. 2016) but many native species of fish are listed as endangered and many species are confused with exotic species as well. Notably, there is controversy about identification of many species belonging to the same genus.

Perciforms, or perch-like fish, can be considered the dominant vertebrates in the world's oceans. They occupy important positions in ecosystems, serving as both predators and prey and frequently taking part in mutually-beneficial relationships with other species, as in the case of the cleaner fish which eat parasites of larger fish. For thousands of years, perciforms have also been highly significant for humans but some of them are now seriously threatened by overfishing (DOF 2013).

Gobies, family Gobiidae, are among the most substantial fish families, with more than 2000 species in 200 genera worldwide and a long taxonomic history (van Tassell et al. 1998). They are poorly explored in the freshwater of Bangladesh.

*Author for correspondence. mehnustabassum77@gmail.com

(c) 2016 Zoological Society of Bangladesh DOI: 10.3329/bjz.v44i2.32757 
Only 18 species under 15 genera are recorded from Bangladesh. Due to habitat destruction and indiscriminate fishing this species is now declining. Therefore, an urgent attention is needed to conserve these fishes.

In the past, identification of fish species based on morphological taxonomic keys was commonly used for a wide variety of purposes (Kon et al. 2007, Teletchea et al. 2008). Moreover, not many scientists are trained and interested in taxonomic nowadays leading to a decrease in the number of taxonomists (Tahseen 2014). A technique is therefore needed to provide rapid and accurate identification for use by the non-experts (Hebert et al. 2003). A standard molecular identification technique is necessary as a complement to morphological methods in order to reduce uncertainties in the identification of species. The availability of DNA sequence data of various species has opened the door for molecular based species identification approaches, such as polymerase chain reaction and DNA sequencing (Alcaide et al. 2009). This alternative method of PCR-based identification is more convenient and easier to perform than the taxonomic keys (Tiwary et al. 2012, Ernieenor et al. 2013). The approach can also provide genetic references to validate field identifications made by researchers with limited taxonomic background (Borisenko et al. 2008, Lu et al. 2012). Currently, the most commonly used barcode region for animals is a $50 \mathrm{bp}$ segment of the mitochondrial gene cytochrome oxidase subunit (COI) called the 'Universal' or 'Folmer' region. This region is the standard marker chosen by the barcode of life database (BOLD), which is an online platform for collating and curating DNA barcoding information from around the world (Ratnasingham and Hebert 2007).

\section{MATERIAL AND METHODS}

Two live specimens of gobi fishes were collected from different regions of Bangladesh. Eleotris fusca was collected from Jamuna river of Tangail district and Glossogobius giuris was collected from Himchori stream of Cox's Bazar district using cast net with the help of fishermen. The samples were placed into 95.5\% ethanol immediately after collection. Then the specimens were brought to the Advanced Fisheries and DNA Barcoding Laboratory at the Department of Zoology, University of Dhaka, for further experiment. Fins from each of the samples were collected from the right side of the body and preserved in ethanol at $-20^{\circ} \mathrm{C}$.

DNA extraction: Total genomic DNA was prepared by homogenization of muscle tissues in $500 \mu \mathrm{l}$ extraction buffer containing $100 \mathrm{mM} \mathrm{NaCl}, 50 \mathrm{mM}$ Tris $\mathrm{HCl}$ ( $\mathrm{pH}$ 8.0), $10 \mathrm{mM}$ EDTA and $8 \mathrm{M}$ urea, followed by digestion in $10 \mu \mathrm{l}$ of proteinase $\mathrm{K}$ to a final concentration of $0.4 \mathrm{mg} / \mathrm{ml}$ at $55^{\circ} \mathrm{C}$ for 24 hours. DNA 
was purified by the phenol : chloroform extraction method followed by ethanol precipitation with 0.1 vol. of $3 \mathrm{M}$ sodium acetate and 2 vol. of absolute ethanol at $-20^{\circ} \mathrm{C}$ for 24 hours. The DNA pellets were washed in $70 \%$ ethanol and allowed to dry at $37^{\circ} \mathrm{C}$ for 6 to $10 \mathrm{~min}$. DNA thus prepared was dissolved in $100 \mu \mathrm{TE}$ buffer and stored at $-20^{\circ} \mathrm{C}$ until use. Extracted DNAs were electrophoresed on a 1.0\% low-melting-temperature agarose gel (Nippon Gene) and stained with ethidium bromide for band characterization using ultraviolet transillumination.

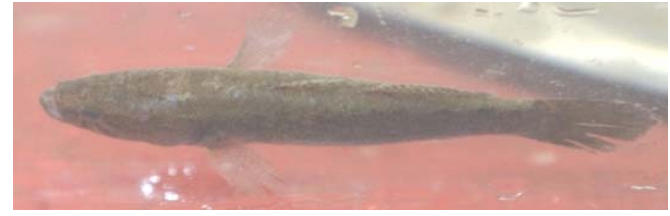

Eleotris fusca (Forster, 1801) (Dusky sleeper)

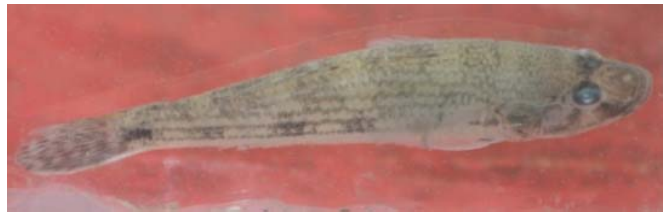

Glossogobius giuris (F. Hamilton, 1822) (Tank goby)

Fig. 1. Samples of gobi fishes.

PCR amplification: In order to amplify $652 \mathrm{bp}$ fragment from the $5^{\prime}$ end of mitochondrial COI gene two primers were used. They were, fish $\mathrm{f} 1$ and fish $\mathrm{r} 1$ (Ward et al. 2005). The sequences of these two primers are given below:

Forward primer (F1): 5' TCAACCAACCACAAAGACATTGGCAC 3'

Reverse primer (R1): 3' TAGACTTCTGGGTGGCCAAAGAATCA 5'

The amplification reactions were performed in a total volume of $25 \mu 1$ which included master mix (1x Invitrogen Platinum Taq Buffer, $0.25 \mathrm{mM}$ each of deoxynucleotide triphosphate (dNTPs), $2.0 \mathrm{mM} \mathrm{MgCl} 2$, and 0.5 units of Taq DNA polymerase), $10 \mathrm{pmol}$ of each primers, $100 \mathrm{ng}$ of genomic DNA,). The reactions were conducted using a PTC-200 DNA Engine Thermal Cycler (Bio-Rad Laboratories, Hercules, CA) under the following conditions: an initial denaturation at $95^{\circ} \mathrm{C}$ for $6 \mathrm{~min} ; 30$ cycles of $94^{\circ} \mathrm{C}$ for $30 \mathrm{sec}, 55^{\circ} \mathrm{C}$ for $30 \mathrm{sec}$ and $72^{\circ} \mathrm{C}$ for $40 \mathrm{sec}$; and concluded with a final elongation step of $72^{\circ} \mathrm{C}$ for $10 \mathrm{~min}$ followed by a hold at $4^{\circ} \mathrm{C}$ (Ivanova et al. 2007). To ensure that the reactions yielded adequate amplicon sizes, PCR products were electrophoresed and visualized on $1.0 \%$ agarose gels containing ethidium bromide (10\%). After observing the amplified DNA in gel electrophoresis, the PCR products then purified. After purification they were sent to Centre for Advanced Research in Science (CARS), University of Dhaka for sequencing. The sequencing was carried out by Sanger sequencing method.

Mitochondrial COI region sequencing: Amplified PCR products were subsequently cleaned by the exo-SAP method (Dugan et al. 2002). Five $\mu 1$ of PCR product, $0.7 \mu \mathrm{l}$ of exonuclease I, 10x buffer (New England Biolabs, MA, USA), 0.5 
$\mu \mathrm{l}$ of exonuclease I and $5.3 \mu \mathrm{l}$ of nanopure water were incubated at $37^{\circ} \mathrm{C}$ for 30 min before being denatured at $80^{\circ} \mathrm{C}$ for $20 \mathrm{~min}$. The purified products were labeled using the BigDye Terminator v.3.1 Cycle Sequencing Kit (Sanger Sequencer) in a total reaction mixture of $10 \mu \mathrm{l}$ containing $4.94 \mu \mathrm{l}$ of nanopure water, $1.94 \mu \mathrm{l}$ of $5 \mathrm{x}$ BigDye buffer ( $400 \mathrm{mM}$ Tris- $\mathrm{HCl} \mathrm{pH} 9.0$ and $10 \mathrm{mM} \mathrm{MgCl} 2$ ), $2 \mu 1$ of $10 \mathrm{p} \mathrm{mol}$ of M13F or M13R, $0.12 \mu \mathrm{l}$ of BigDye Terminator, and $1 \mu 1$ exo SAP products. Sequence PCR products were cleaned up using the ethanol/EDTA precipitation method and sequenced bi-directionally on an ABI $(3130 \times 1)$.

Sequences were identified using BLAST search within nucleotide database to determine the highest homolog. To test the efficiency of DNA barcoding as a species identification tool, a blind sampling test was conducted, in which samples with identity unknown except to the submitting individual, were selected and sequenced.

\section{RESULTS}

A total of two samples of these fishes were collected from the different regions of Bangladesh. These species belong to the genera Eleotris and Glossogobius. Morphometric study was done by observing and measuring the external morphology which include body coloration, shape of body, mouth, head, snout, eye, fin shape, habit and habitat etc. Various parts of the body were measured according to the body-length ratio. (Tables 1 and 2).

Table 1. Average body, head measurement of gobi fishes

\begin{tabular}{|c|c|c|c|c|c|c|c|c|c|c|c|}
\hline \multirow{2}{*}{$\begin{array}{l}\text { Sl. } \\
\text { No. }\end{array}$} & \multirow{2}{*}{$\begin{array}{l}\text { Scientific } \\
\text { name }\end{array}$} & \multicolumn{7}{|c|}{$\begin{array}{c}\text { Body measurement } \\
\text { (average) }\end{array}$} & \multicolumn{3}{|c|}{$\begin{array}{l}\text { Head measurement } \\
\text { (average) }\end{array}$} \\
\hline & & $\begin{array}{c}\mathrm{TL} \\
(\mathrm{cm})\end{array}$ & $\begin{array}{c}\mathrm{SL} \\
(\mathrm{cm})\end{array}$ & $\begin{array}{l}\text { PDL } \\
(\mathrm{cm})\end{array}$ & $\begin{array}{l}\mathrm{BD} \\
(\mathrm{cm})\end{array}$ & $\begin{array}{l}\mathrm{PD} \\
(\mathrm{cm})\end{array}$ & $\begin{array}{l}\mathrm{HL} \\
(\mathrm{cm})\end{array}$ & $\begin{array}{c}\mathrm{ED} \\
(\mathrm{mm})\end{array}$ & $\begin{array}{l}\text { Pr.OL } \\
(\mathrm{mm})\end{array}$ & $\begin{array}{l}\text { Po.OL } \\
(\mathrm{mm})\end{array}$ & $\begin{array}{c}\text { IOL } \\
(\mathrm{mm})\end{array}$ \\
\hline 1 & Eleotris fusca & 7.3 & 6.0 & 1.6 & 1.2 & 0.8 & 2.1 & 0.4 & 0.4 & 1.4 & 0.6 \\
\hline 2 & $\begin{array}{l}\text { Glossogobius } \\
\text { giuris }\end{array}$ & 13.2 & 10.5 & 1.2 & 1.1 & 1.0 & 3.6 & 0.5 & 1.2 & 1.7 & 0.3 \\
\hline
\end{tabular}

Table 2. Average number of fin/spines measurements of gobi fishes

\begin{tabular}{|c|c|c|c|c|c|c|c|c|c|c|}
\hline \multirow{3}{*}{$\begin{array}{l}\text { Sl. } \\
\text { No. }\end{array}$} & \multirow{3}{*}{$\begin{array}{l}\text { Scientific } \\
\text { name }\end{array}$} & \multicolumn{5}{|c|}{ Fin base length (mm) (average) } & \multicolumn{4}{|c|}{$\begin{array}{l}\text { Number of fin rays/spines } \\
\text { (average) }\end{array}$} \\
\hline & & \multicolumn{2}{|c|}{ DFB } & \multirow[t]{2}{*}{ P1FB } & \multirow[t]{2}{*}{$\mathrm{P} 2 \mathrm{FB}$} & \multirow[t]{2}{*}{ AFB } & \multicolumn{2}{|c|}{ DFR } & \multirow[t]{2}{*}{ P2FR } & \multirow[t]{2}{*}{ AFR } \\
\hline & & 1 st & 2 nd & & & & D1 & D2 & & \\
\hline 2 & Eleotris fusca & 0.6 & 9.5 & 5.3 & 2.0 & 3.8 & 6 & 1 & 1 & 1 \\
\hline 3 & Glossogobius giuris & 1.5 & 2.2 & 1.0 & 3.0 & 1.1 & 6 & 1 & & 1 \\
\hline
\end{tabular}

$\mathrm{TL}=$ Total length $\mathrm{FL}=$ Fork length, $\mathrm{SL}=$ Standard length, $\mathrm{PDL}=$ Pre-dorsal length, $\mathrm{P} 1 \mathrm{FR}=$ Pectoral fin rays, $\mathrm{P} 2 \mathrm{FR}=\mathrm{Pelvic}$ fin rays, $A F R=$ Anal fin rays, $P D=$ Peduncle depth, $\mathrm{HL}=$ Head length, $\mathrm{ED}=$ Eye diameter, $\mathrm{DFR}=\mathrm{Dorsal}$ fin rays $/ \mathrm{spines}$ $\mathrm{DFB}=$ Dorsal fin base, $\mathrm{PFB}=$ Pectoral fin base, $\mathrm{P} 1 \mathrm{FB}=$ First pelvic fin base, $\mathrm{P} 2 \mathrm{FB}=$ Second pelvic fin base, AFB = Anal fin base, IOL = Inter-orbital length, BD = Body depth, CFR = Caudal fin rays, Pr.OL = Pre-orbital, Po.OL = Post-orbital. 
DNA extraction: Genomic DNA from each specimen was extracted successfully after collecting tissue samples from a region of the pectoral fin (Fig. 2A).

PCR amplification: The extracted DNA from two gobi fishes was amplified by PCR amplification of cytochrome oxidase subunit 1 (COI) gene using COI specific primer which has a product size of around $650 \mathrm{bp}$ (Fig. 2B).

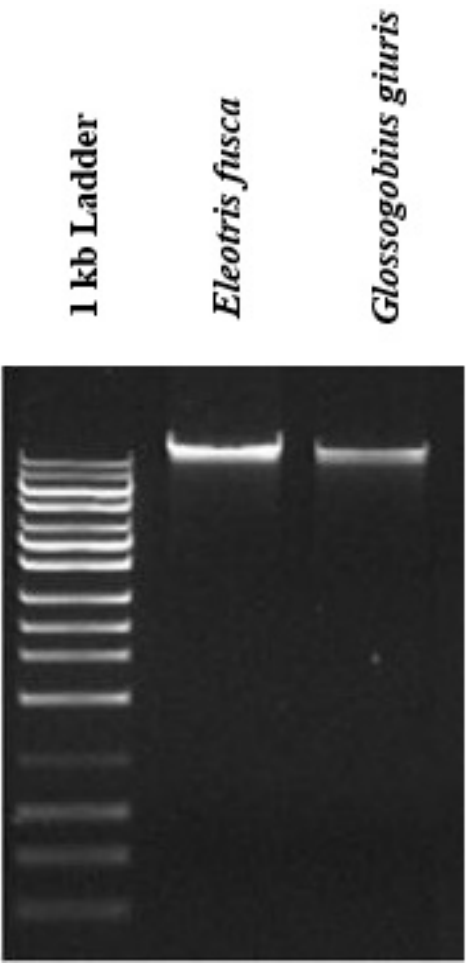

(A)

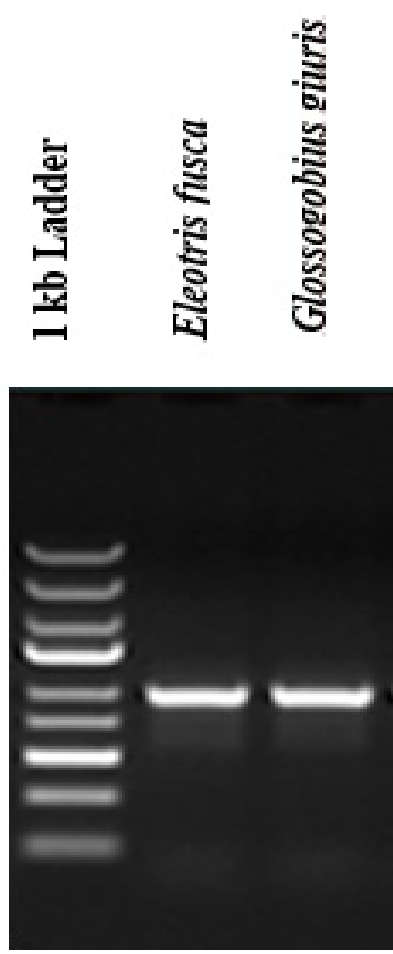

(B)

Fig. 2. A. Isolated DNA of E. fusca and G. giuris in 1\% agarose gel. B. PCR products of $\mathrm{CO} 1$ gene regions from two different gobi species in $1 \%$ agarose gel.

The mitochondrial cytochrome oxidase I (COI) region of all samples was successfully amplified using PCR. The comprehensive barcoding identification results were based on GenBank databases. Database revealed definitive identity matches in the range of $96-98 \%$ for consensus sequences of two species (Eleotris fusca, Glossogobius giuris). GenBank-based identification for all species yielded an alignment E-value of 0.0 (Table 3). Multiple sequence alignment was done using examined sequences and downloaded sequences. 

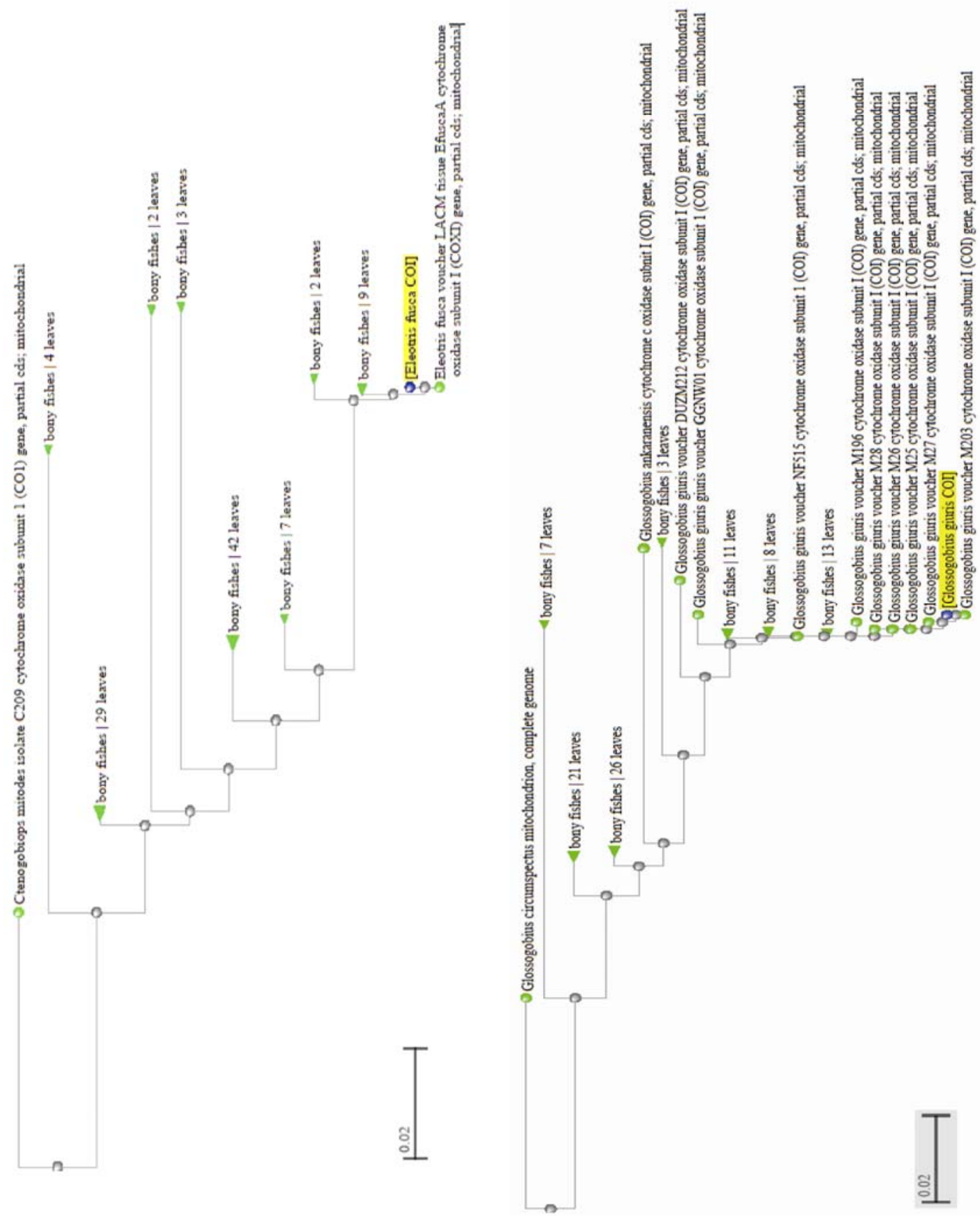

A

B

Fig. 3. BLAST search result for COI identifications. A. BLAST pairwise tree (Fast minimum evolution tree method) for E. fusca and B. G. giuris. 
Table 3. Result obtained from genbank BLAST search for COI gene of E. fusca and G. giuris

\begin{tabular}{|c|c|c|c|c|c|c|}
\hline Description & $\begin{array}{l}\text { Max } \\
\text { score }\end{array}$ & $\begin{array}{l}\text { Total } \\
\text { score }\end{array}$ & $\begin{array}{l}\text { Query } \\
\text { cover }\end{array}$ & \begin{tabular}{l|c}
$y$ & $E$ \\
$y$ & value
\end{tabular} & Ident & Accession \\
\hline (1) Eleotris fusca voucher LACM tissue EfuscaA cytochrome oxidase subunit। (COXI) gene, partial cds; mitochondrial & 1129 & 1129 & $100 \%$ & 60.0 & $99 \%$ & AY722172.1 \\
\hline [- Eleotris fusca isolate Efusca 14026 crtochrome oxidase subunit। (COI) gene, partial cds: mitochondrial & 1123 & 1123 & $100 \%$ & 60.0 & $99 \%$ & $\underline{\text { KU727892.1 }}$ \\
\hline - Eleotris tusca isolate Efusca1428 cytochrome oxidase subunit/ (col) gene, partial cds; mitochondrial & 1123 & 1123 & $100 \%$ & 60.0 & $99 \%$ & $\underline{\text { KU727890.1 }}$ \\
\hline Eleotris fusca voucher BlF0417 cytochrome oxidase subunit 1 (COl) gene, partial cds: mitochondrial & 1123 & 1123 & $100 \%$ & $6 \quad 0.0$ & $99 \%$ & $\underline{\mathrm{KT} 960772.1}$ \\
\hline Eleotris fusca isolate 14026 cytochrome oxidase subunitl ( $\mathrm{COl}$ ) gene, partial cds: mitochondrial & 1123 & 1123 & $3100 \%$ & $6 \quad 0.0$ & $99 \%$ & $\underline{\text { KU232392.1 }}$ \\
\hline Eleotris fusca isolate Efusca 14024 cytochrome oxidase subunit/ (COI) gene, partial cds; mitochondrial & 1118 & 1118 & $100 \%$ & 60.0 & $99 \%$ & $\underline{\text { KU727895.1 }}$ \\
\hline Description & $\begin{array}{l}\text { Max } \\
\text { score }\end{array}$ & $\begin{array}{l}\text { Total } \\
\text { score }\end{array}$ & $\begin{array}{l}\text { Query } \\
\text { cover }\end{array}$ & $\begin{array}{c}E \\
\text { value }\end{array}$ & Ident & Accession \\
\hline Glossocobius qiuris voucher M203 cytochrome oxidase subunit I (COl) qene, partial cds; mitochondrial & 1125 & 1125 & $99 \%$ & 0.0 & $99 \%$ & $\underline{\mathrm{KT}} 364553.1$ \\
\hline Glossogobius qiuris voucher M28 crtochrome oxidase subunitl ( COI) gene, partial cds: mitochondrial & 1114 & 1114 & $99 \%$ & 0.0 & $99 \%$ & $\underline{\mathrm{KT} 364542.1}$ \\
\hline Glossogobius qiuris voucher M26 cytochrome oxidase subunit/ ( coll) gene. partial cds; mitochondrial & 1114 & 1114 & $99 \%$ & 0.0 & $99 \%$ & $\underline{\mathrm{KT}} 364540.1$ \\
\hline Glossogobius giuris voucher M25 cytochrome oxidase subunit। ( COl) gene, partial cds: mitochondrial & 1114 & 1114 & $99 \%$ & 0.0 & $99 \%$ & $\underline{\mathrm{KT} 364539.1}$ \\
\hline Glossogobius qiuris voucher M27 cytochrome oxidase subunitl (col) gene, partial cds; mitochondrial & 1109 & 1109 & $99 \%$ & 0.0 & $99 \%$ & $\underline{\mathrm{KT} 364541.1}$ \\
\hline Glossogobius qiuris voucher NF515 cytochrome oxidase subunit 1 (COI) gene, partial cds; mitochondrial & 1109 & 1109 & $99 \%$ & 0.0 & $99 \%$ & $\underline{\mathrm{JX} 983307.1}$ \\
\hline Glossogobius qiuris isolate $8042 U$ cytochrome coxidase subunit। (COI) gene, partial cds; mitochondrial & 1103 & 1103 & $99 \%$ & 0.0 & $99 \%$ & $\underline{K X 245075.1}$ \\
\hline
\end{tabular}

Sequence output: The sequence data were transferred to FASTA format and BLASTED within nucleotide database for the authentication of the morphological identification. Two samples were sequenced and BLASTED. The nucleotide sequences of these samples matched to two different species (Fig. 3). Most of the identifications were similar to morphological identification.

\section{DISCUSSION}

In the past, mainly morphological characters were used for inferring fish phylogenetic relationships to understand their speciation. In the case of gobi fishes, it is difficult to differentiate the species because of the similarity in external morphology. Therefore, the reconstructed phylogenetic trees based on morphology were controversial due to the complex evolutionary changes in either morphological or physiological characters. Recent advances in molecular biology have changed this situation such as the genetic analysis of mtDNA has been conducted to resolve the controversial taxonomic problem (Ruber et al. 2006, Erguden et al. 2010) and have proved that molecular markers can facilitate the discrimination of morphologically similar species. Many workers 
have studied the gobi fishes and reported that they are monophyletic (Kartavtsev et al. 2007). Molecular species identification using DNA barcoding has been applied successfully elsewhere. In this study, the COI region of the mitochondrial DNA has been sequenced to create a set of barcode sequences to identify two gobi fish from two different genera.

Samples of two gobi fishes were collected from different regions of Bangladesh. At first, the morphometric and meristic analyses were done. It revealed that Glossogobius giuris was slightly larger than Eleotris fusca. But their body colour, head, eyes are closely related to each other. It created some confusion between the two species which demonstrates the necessity of molecular scrutiny. Molecular identification of these species were performed by DNA barcoding. However, the COI sequence of two gobi fishes is highly similar to the available sequences in genbank. The successful molecular identification is valuable because of the taxonomic ambiguities. This study exhibits that COI gene enables accurate animal species identification where adequate reference sequence data exist. If DNA sequences for potential animals are not represented in the database, sequenced identification may be misidentified. DNA sequences analysis also relies heavily on the robustness of available sequence for the target species in the gene library.

\section{CONCLUSION}

To determine the species boundaries among members of the Gobiidae and Eleotridae, the mitochondrial COI gene sequences obtained in the present study could be considered a valuable tool for efficient use of DNA barcodes to identify and discriminate species. From this study, it is possible to produce the molecular database that assembles the molecular characteristics of these species. This sequence can also be used in further studies to determine the genetic divergence of gobi fishes in different geographical distribution. Bangladesh has to assist the management of their fish population in wild to prevent them from becoming extinct. Fishermen and local people should be made aware to conserve these species. Hence, molecular identification will help fish experts to identify the cryptic species accurately and produce hybrid in near future.

Acknowledgement: The authors express their sincere thanks to the Ministry of Science and Technology, Government of the People's Republic of Bangladesh for funding this research. 


\section{LITERATURE CITED}

ALCAIDE, M., RICO, C., RUIZ, S., SORIGUER, R., MUNOZ, J. and FIGUEROLA, J. 2009. Disentangling vector-borne transmission networks: A universal DNA barcoding method to identify vertebrate hosts from arthropod blood meal. PLOS ONE 4: (9).

BORISENKO, A.V., LIM, B.K., IVANOVA, N.V., HANNER, R.H. and HEBERT, P.D.N. 2008. DNA barcoding in surveys of small mammal communities: A field study in Suriname. Molecular Ecology Resources 8: 471-479.

DOF. 2013. National fish week 2013 compendium. Department of Fisheries, Ministry of Fisheries and Livestock, Government of the People's Republic of Bangladesh, pp: 1-144.

DUGAN, K. A. et al. (2002). An improved method for post-PCR purification for mtDNA sequence analysis. Journal of Forensic Sciences 47: 811-818.

ERGUDEN, D., GURLEK, M., YAGLIOGLU, D. and TURAN, C. 2010. Genetic identification and taxonomic relationship of Mediterranean Mugilid species based on mitochondrial 16S rDNA sequence data. J. Ani.Veter. Adv. 9: 336-341.

ERNIEENOR, F.C.L., AYE, T.W., MARIANA, A. and HO, T.M. 2013. PCR amplification of mitochondrial cytochrome $b$ gene of animals in Malaysia. The Experiment 15(2): 1064-1071.

HEBERT, P.D.N., CYWINSKA, A., BALL, S.L. and DEWAARD, J.R. 2003. Biological identifications through DNA barcodes. Proceedings of the Royal Society Biological Sciences 270: 313-321.

IVANOVA, N.V., ZEMLAK, T.S., HANNER, R.H. and HEBERT, P.D.N. 2007. Universal primers cocktails for fish DNA barcoding. Mole. Ecol. Notes 7(4): 544-548.

KARTAVTSEV, Y.P., JUNG, S.O., LEE, Y.M., BYEON, H.K. and LEE, J.S. 2007. Complete mitochondrial genome of the bullhead torrent catfish, Liobagrusobesus (Siluriformes, Amblycipididae): Genome description and phylogenetic considerations inferred from the Cyt $b$ and 16S rRNA genes. Gene 396: 13-27.

KON, T., YOSHINO, T., MUKAI, T. and NISHIDA, M. 2007. DNA sequences identify numerous cryptic of the vertebrate: Alesson from the gobioid fish Schindleria. Molecular Phylogenetics and Evolution 44(1): 53-62.

LU, L., CHESTER, D., ZHANG, W., LI, G., MA, Y., MA, H., SONG, X., WU, H., MENG, F., ZHU, C., and LIU, Q. 2012. Small mammal investigation in spotted fever focus with DNA-barcoding and taxonomic implications on rodents species from Hainan of China. PLoS ONE 7(8): e43479.

RAHMAN, M.M., RAHMAN, M.B., OKAZAKI, E. and RITHU, M.N.A. 2016. Assessment of species specificity of fishing gears and fish diversity status in the Andharmanik river of coastal Bangladesh. J. Fish. Aquat. Sci. 11: 361-369.

RATNASINGHAM, S. and HEBERT, P.D.N. 2007. BOLD: The barcode of life data system (http:/ / www.barcodinglife.org). Molecular Ecology Notes 7(3): 355-364.

RUBER, L.R., BRITZ, R., and ZARDOYA, Y.R., 2006. Molecular phylogenetics and evolutionary diversification of labyrinth fishes (Perciformes; Anabantoidei). Syst. Biol. 55: 374-397.

TAHSEEN, Q. 2014. Taxonomy - The crucial yet misunderstood and disregarded tool for studying biodiversity. Journal of Biodiversity and Endangered Species 2(3): 1-9.

TEletChEA, F., BERNillon, J., DUfFrAisse, M., LAUDET, V. and HANNI, C. 2008. Molecular identification of vertebrate species by oligonucleotide microarray in food and forensic samples. Journal of Applied Ecology 45: 967-975. 
TIWARY, P., KUMAR, D., RAI, M. and SUNDAR, S. 2012. PCR-RFLP based method for molecular identification of sand fly species Phlebotomu sargentipes, Phlebotomu spapatasi and Sergentomyia babu found in India. Journal of Medical Entomology 49(6): 1515-1518.

VAN, TASSELL., L, D, VAN, VLECK., and K. E. GREGORY. 1998. Bayesian analysis of twinning and ovulation rates using a multiple-trait threshold model and Gibbs sampling. Journal of Animal Science. 76: 8: 2048-2061.

WARD, RD., ZEMLAK, T,S., INNES, B.H., LAST, PR., and HEBERT, PDN., 2005. DNA barcoding Australia's fish species. Philosophical Transactions of the Royal Society of London. Series B, Biological Sciences. 360: 1847-1857.

(Manuscript received on 24 October, 2016; revised on 15 November, 2016) 